\title{
Coupled thermal and structural analysis of roller compacted concrete arch dam by three-dimensional finite element method
}

\begin{abstract}
This paper focuses on the development, verification and application of a three-dimensional nite element code for coupled thermal and structural analysis of roller compacted concrete arch dams. The Ostour Arch dam located on Ghezel-Ozan River, Iran, which was originally designed as conventional concrete arch dam, has been taken for the purpose of verication of the nite element code. In this project, RCC technology has been ascertained as an alternative method to reduce the cost of the project and make it competitive. The thermal analysis has been carried out taking into account the simulation of the sequence of construction, environmental temperature changes, and the wind speed. In addition, the variation of elastic modulus with time has been considered in this investigation using Concard's model. An attempt was made to compare the stresses developed in the dam body five years after the completion of the dam with those of end of the construction. It was seen that there is an increase in the tensile stresses after five years over stresses obtained immediately at the end of construction by $61.3 \%$.
\end{abstract}

Keyword: Arch RCC dam; Thermal analysis; Stress analysis; Finite element modeling 